\title{
Runoff generation at the small permafrost river basin in Eastern Siberia: data analysis and hydrological modeling
}

\author{
Andrey Kalugin ${ }^{1 *}$, and Liudmila Lebedeva ${ }^{2}$ \\ ${ }^{1}$ Water Problems Institute RAS, Gubkina 3, 119333, Moscow, Russia \\ ${ }^{2}$ Melnikov Permafrost Institute SB RAS, Merzlotnaya 36, 677010, Yakutsk, Russia
}

\begin{abstract}
The study aims at the analysis of the long-term hydrometeorological data and hydrological modelling at the small permafrost Shestakovka river basin. The basin has postponed reaction to precipitation on different time scales from days to years. Annual, seasonal and monthly streamflow has higher correlation with precipitation sum for corresponding and antecedent time intervals than for the corresponding period only. It suggests importance of water storage and slow water release in the runoff generation that could be related to the suprapermafrost talik aquifers found in the river basin. A spatially distributed physically-based ECOMAG model was applied to the Shestakovka River basin. Evaluation of the simulated river runoff, soil moisture and snow water equivalent was carried out over a period 1990-2014. Obtained NSE 0.59 and BIAS 3\% could be considered as satisfactory modelling results taking into account high inter annual and seasonal observed streamflow variability under much less variable meteorological conditions. Better understanding and modelling of the complex interactions between permafrost and hydrological processes is important for development of reliable flood forecasts and long-term future projections under changing climate and growing economical interests to cold regions.
\end{abstract}

\section{Introduction}

Permafrost hydrology in Siberia is poorly investigated and undergoes significant changes. The hydrological cycle is influenced by permafrost and related cold region processes in several ways, for instance time-variable frozen aquiclude, limited connectivity between surface and groundwater, long snow season and period of river ice cover $[1,2]$. Although many modelling studies have been conducted for the permafrost dominated river basins [36], the understanding and representation of the permafrost-related hydrological processes at small scale remain a challenge. Our study aims at better understanding of river runoff generation processes at the small permafrost river basin through analysis of the long-term hydrometeorological data and hydrological modelling.

\footnotetext{
* Corresponding author: kalugin-andrei@mail.ru
} 
The studied Shestakovka River watershed with area $170 \mathrm{~km}^{2}$ is located in $15 \mathrm{~km}$ to south-west of Yakutsk within the erosion-denudational slope of the ancient accumulative plain with absolute elevation of $150-280 \mathrm{~m}$. The permafrost thickness is $200-400 \mathrm{~m}$. The upper $40 \mathrm{~m}$ of the section are represented by quartz-feldspar sands with rare inclusions of silty sandy loam and loam. The climate is cold and dry with mean annual air temperature $9.5^{\circ} \mathrm{C}$, precipitation $240 \mathrm{~mm} /$ year (1950-2015). Dominant landscapes are pine $(47 \%$ of the watershed area) and larch (38\%) forests. Mires and bogs cover rest of the watershed.

In the study we used data from the field campaigns in 2015-2018, expeditionary data archives from 1979-1985, long-term streamflow and meteorological data available for the watershed from 1951 to 2015 from the Kamyrdagystakh hydrological gauge and Yakutsk weather station. Correlation analysis was employed to describe relations between precipitation and streamflow on different time scales - days, months, seasons and years. Annual streamflow and precipitation were calculated for the hydrological years.

The hydrological modeling was conducted using the ECOMAG software [7] to study runoff generation in the Shestakovka river basin. The model describes the spatial distribution of snow cover formation and melt, soil freezing and thawing, vertical heat and moisture transfer in frozen and unfrozen soil, evapotranspiration, surface and subsurface flow, groundwater flow and streamflow transformation along the river network.

\section{Data analysis}

Mean annual Shestakovka River streamflow amounts to $25 \mathrm{~mm}$ that is approximately $10 \%$ of the mean annual precipitation. On average evapotranspiration considerably dominates over streamflow in the water balance. Annual streamflow has low correlation with annual precipitation of the corresponding year $(\mathrm{r}=0.45)$, slightly higher correlation with annual precipitation of the antecedent year $(\mathrm{r}=0.50)$ and no correlation with annual precipitation for the year before antecedent one $(r=0.17)$. Correlation of annual streamflow with precipitation sum for corresponding and antecedent years $(r=0.62)$ is similar to one with precipitation sum for corresponding and two antecedent years $(\mathrm{r}=0.63)$. The relation is weaker with precipitation sum for corresponding and three antecedent years. Found relationships between annual streamflow and precipitation are shown at the Fig. 1. They agree with the fact that soil moisture in forested landscapes in Central Yakutia depends on precipitation of the antecedent year [8].

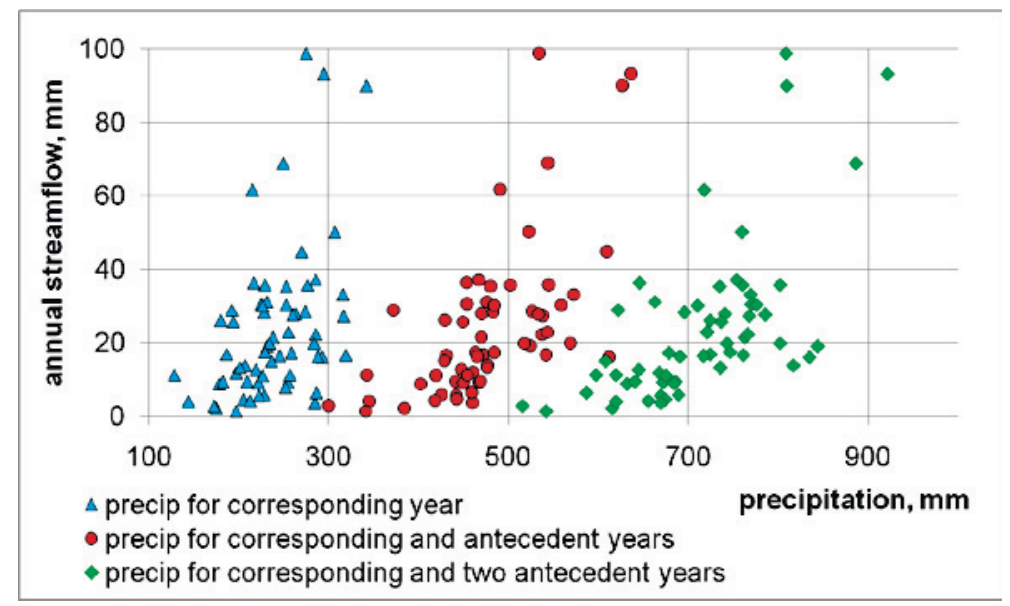

Fig. 1. Relationships between Shestakovka river streamflow and precipitation sum for corresponding, antecedent and two antecedent years. 
On average half of the annual Shestakovka River streamflow occurs during the spring flood in April and May. Fraction of the spring freshet in the annual streamflow varies from year to year from 3 to $82 \%$. Spring freshet correlates better with precipitation from June of the antecedent year to May of the corresponding year $(r=0.7)$ than with winter precipitation (October-May, $r=0.49$ ) or antecedent summer precipitation only (JuneSeptember, $r=0.51)$. Spring streamflow shows high correlation with the streamflow for antecedent August-September $(\mathrm{r}=0.75)$. Found relationships suggest that spring freshet equally depends on snow and previous summer wetness conditions.

Summer streamflow (June-August) has low correlation with precipitation for the corresponding months $(\mathrm{r}=0.34)$ and slightly higher correlation with precipitation sum for the period from May to August $(r=0.48)$. Snow amount does not influence summer flow.

Flow of separate months depends on precipitation sum for corresponding and antecedent months. June and September flow has stronger correlation with precipitation of antecedent month $(\mathrm{r}=0.50, \mathrm{r}=0.59)$ than of the corresponding month $(\mathrm{r}=0.41, \mathrm{r}=0.20)$. July flow has similar correlations with July $(r=0.55)$ and June precipitation $(r=0.49)$. August is the only month when flow has high correlation with precipitation of the same month $(\mathrm{r}=0.63)$.

Analysis of daily flow from June to complete river freeze-up in October or November showed that it correlates with precipitation sum for antecedent 14-18 days $(\mathrm{r}=0.52)$. Maximum daily discharges of summer and autumn floods higher $100 \mathrm{l} / \mathrm{s}$ has closer correlation with precipitation sum for 18-23 days before the event.

\section{Hydrological modelling}

The Harmonized World Soil Database (2 types of soils) and Global Land Cover Characterization ( 8 types of landscapes) were used to determine model parameters in the Shestakovka River basin. Schematization of the basin and river network was carried out based on the Arctic DEM with a spatial resolution of $10 \mathrm{~m}$. Using the schematization, the catchment was divided into subbasins, which were the calculation units of the model. The total number of subbasins in the Shestakovka catchment up to the Kamyrdagystakh gauging station was 35 (Fig. 2). Thus, each subbasin has a specific set of soil types, landscapes, and elevation that determine the model parameters.

The model's boundary conditions are based on daily data of air temperature and humidity, precipitation measured at 2 weather stations Yakutsk and Pokrovsk, located 15 $\mathrm{km}$ to the North-East and $45 \mathrm{~km}$ to the South of the Shestakovka catchment, respectively. Calculations of the river runoff with a daily time step and spatial resolution equal to the size of subbasin (about $5 \mathrm{~km}^{2}$ ) were performed for the Kamyrdagystakh gauging station. A quantitative assessment of the accuracy of modeling the daily runoff was carried out using the NSE and BIAS criteria for the period 1990-2014 (Fig. 3).

The values of statistical criteria for the period 1990-2014 were NSE 0.59 and BIAS $3 \%$. The NSE criterion was positive for 17 years and for 10 years with values greater than 0.5 , and the maximum value was 0.88 . The correlation coefficient between the observed and simulated annual flow of the Shestakovka River was 0.78 for the period 1990-2014, and for the maximum daily discharges was 0.69 . The simulated and observed streamflow has better agreement in wet years than in dry years. 


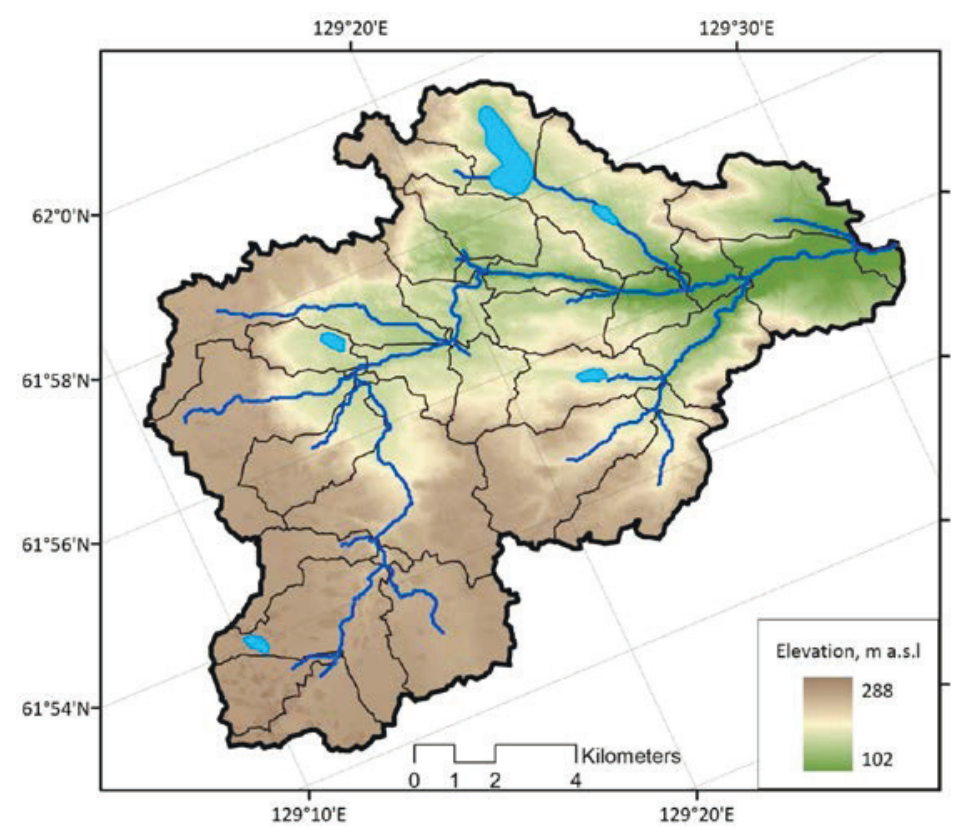

Fig. 2. Schematization of the Shestakovka River basin
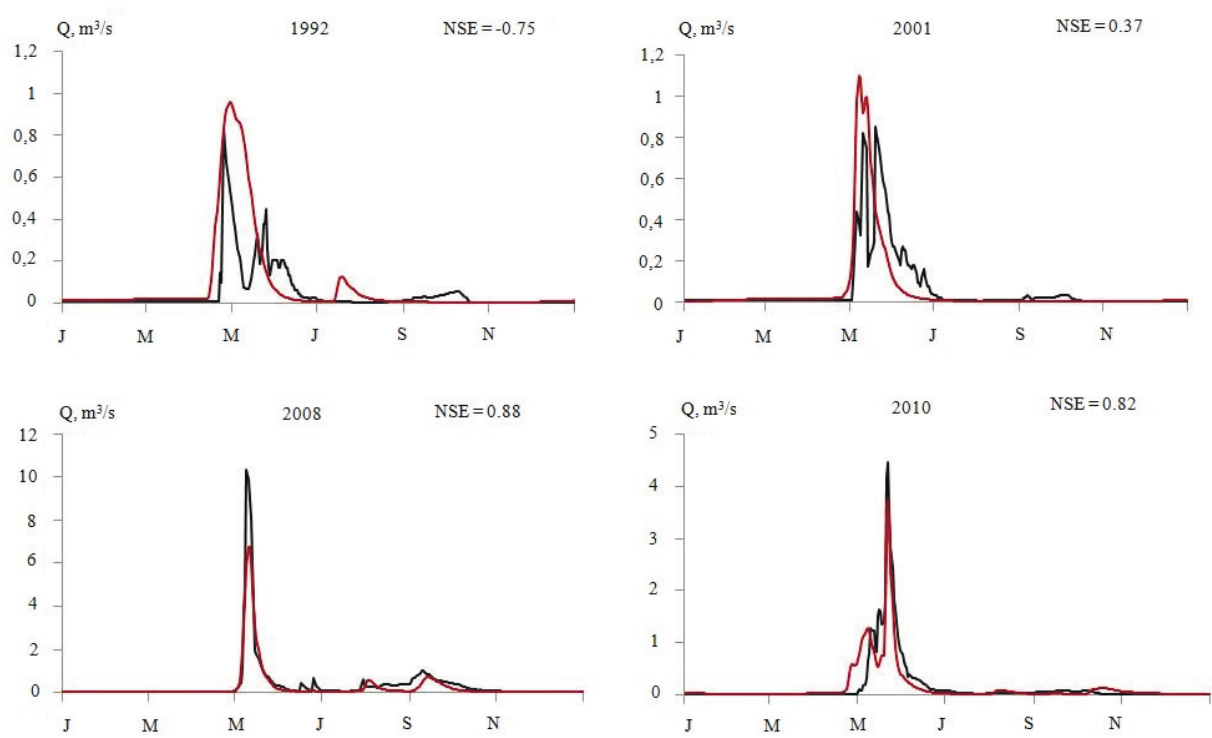

Fig. 3. Daily observed (black) and simulated (red) hydrographs of the Shestakovka River at the Kamyrdagystakh gauging station in low (1992, 2001), middle (2010) and high (2008) water years.

In addition to the runoff, the accuracy of soil moisture and snow water equivalent modeling was evaluated for the Shestakovka River basin. We used data from the measured volumetric soil moisture at a depth of $30 \mathrm{~cm}$ for the period 1981-1983 near Lake Malaya Chabyda, located in the northern part of the catchment. Taking into account 51 measured values over 3 years, the systematic overestimation of volumetric soil moisture by the model was $0.2 \%$ with a correlation coefficient of 0.1 (Fig. 4 ). The greatest discrepancy between 
the calculated and measured soil moisture was found for the cold period, when the topsoil was frozen, and modeled water (ice) content is constant, while the variability of the measured values was generally large. Soil sampling for water and ice content estimation in the field was done at the same plot but in slightly different points every time. Thus, measured values in winter mostly relates to spatial variability of the ice content in the soil. If we evaluate consistency only for the warm period from May to September, the correlation coefficient was 0.5 with BIAS of $-0.1 \%$. To assess the accuracy of modeling snow water equivalent, we used data from snow course survey in the forest near the Yakutsk weather station for the period 1990-2014. The total number of measurements of snow water equivalent was 291, but in 1997-2006 there were 7 measurements per season, before 1997 and since 2007 there were 15 values per season. Fig. 5 shows the observed and simulated values (averaged-basin) of snow water equivalent over a multi-year period.

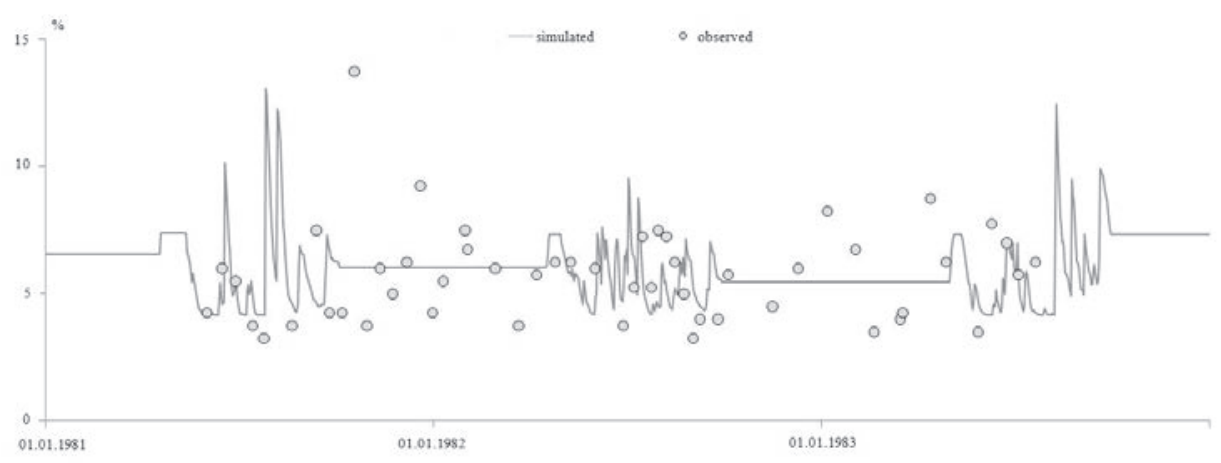

Fig. 4. Measured and simulated values of the volumetric soil moisture at a depth of $30 \mathrm{~cm}$ near Lake Malaya Chabyda.

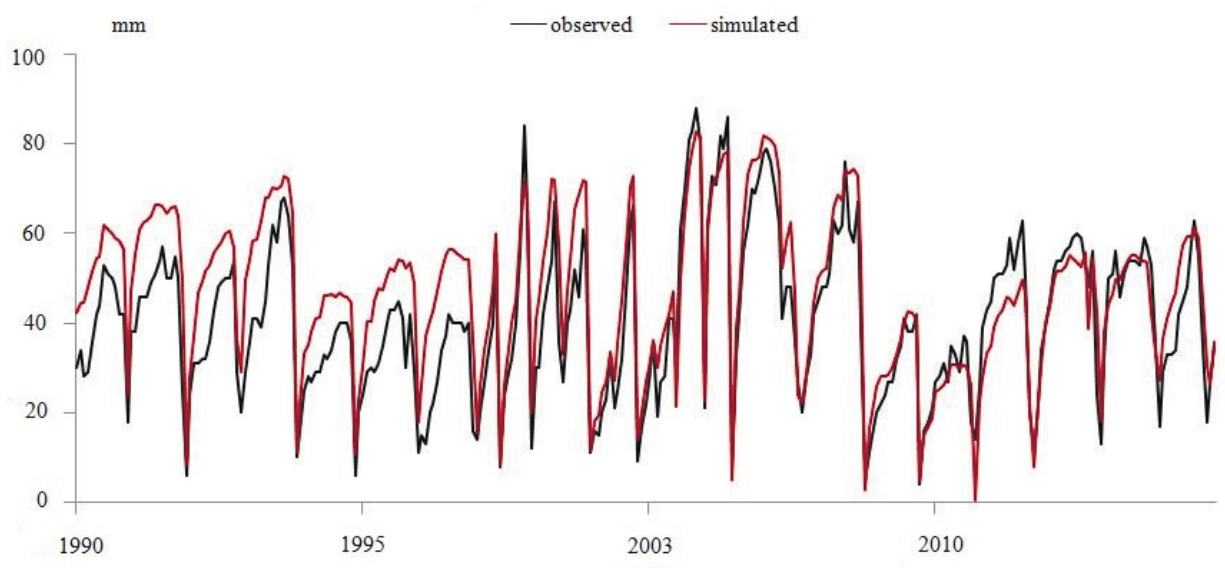

Fig. 5. Measured and simulated values of the snow water equivalent in the Shestakovka River basin over a multi-year period.

The model overestimates the amount of snow water equivalent by $15 \%$, while the correlation coefficient and NSE were 0.89 and 0.66 , respectively. However, mostly the calculated values exceed the measurements for the period up to 1997. Systematic error of the calculated snow water equivalent was $6 \%$ for the period 1997-2014, the correlation coefficient was 0.93 , and the NSE criterion was 0.84 . 


\section{Conclusion}

The obtained result of the runoff formation modeling is acceptable, given the high inter annual and seasonal variability of the observed Shestakovka River flow under much less variable meteorological conditions. Modeling efficiency is comparable with the published simulation results using the Hydrograph model [9]. Modelled streamflow shows higher correlation with precipitation than observed values. The model simulates faster and stronger streamflow response to snowmelt and rainfall than the river shows in reality. Processes of water storage and slow release in the basin are not fully understood and represented in the model. Presumably large water storages of the suprapermafrost talik aquifers [10] could explain slow hydrological response of the river. Evapotranspiration considerably dominates over streamflow in the water balance structure that also could be a reason of weak correlation between streamflow and precipitation as well as lowered modeling efficiency in dry years

Similar hydrological behavior is typical for larger rivers in Central Yakutia [11, 12]. Understanding and modeling of the complex interactions between permafrost and hydrological processes is important for reliable flood forecasts and future projections under changing climate and growing economical interests to cold regions.

This research was supported by the Russian Science Foundation (project no. 19-77-00055 - part of hydrometeorological data analysis) and the grant of the president of the Russian Federation for young scientists (project no. MK-1753.2020.5 - part of hydrological modeling).

\section{References}

1. M.-k. Woo, Permafrost hydrology (Springer-Verlag, 2012)

2. M. A. Walvoord, B. L. Kurylyk, Vadose Zo. J., 15, 6 (2016)

3. O. Semenova, L. Lebedeva, Yu. Vinogradov, Hydrogeol. J., 21 (1), 107-119 (2013)

4. J. W. Pomeroy, D. M. Gray, T. Brown et al., Hydrol. Process., 21, 2650-2667 (2007)

5. A. Gelfan, D. Gustafsson, Yu. Motovilov, B. Arheimer, A. Kalugin, I. Krylenko, A. Lavrenov, Climatic Change, 141, 499-515 (2017)

6. M. K. MacDonald, T. A. Stadnyk, S. J. Déry, M. Braun, D. Gustafsson, K. Isberg, B. Arheimer, GRL, 45, 7561-7570 (2018)

7. Y. Motovilov, L. Gottschalk, K. Engeland, A. Rodhe, Agric. For. Meteorol., 98-99, 257 (1999)

8. T. Ohta, T. C. Maximov, A. J. Dolman, T. Nakai, M. K. van der Molen, A. V. Kononov, A. P. Maximov, T. Hiyama, Y. Iijima, E.J. Moors, H. Tanaka, T. Toba, H. Yabuki, Agric. Forest Meteorol., 140, 1941-1953 (2008)

9. L.S. Lebedeva, Formation of river flow in the permafrost zone of Eastern Siberia, Cand. geogr. sci. diss. Abstr., 22 (2018)

10. L. S. Lebedeva, K. I. Bazhin, I. I. Khristoforov, A. A. Abramov, N. A. Pavlova, V. S. Efremov, V. V. Ogonerov, A. M. Tarbeeva, M. P. Fedorov, N. V. Nesterova, O. M. Makarieva, Kriosfera Zemli, 23(1), 40-50 (2019)

11. K. P. Voskresensky, Norm and variability of annual streamflow of rivers of Soviet Union. (Hydrometeoizdat, 1962)

12. Resources of surface waters of USSR, 17 (Hydrometeoizdat, 1967) 